\title{
SZUBJEKTÍV EGÉSZSÉGÉRZET ÉS A FIZIKAI AKTIVITÁS KAPCSOLATÁNAK VIZSGÁLATA KÖZÉPISKOLÁSOK KÖRÉBEN
}

\author{
Szerző: \\ Lektorok: \\ Szerdahelyi Zoltán \\ Debreceni Egyetem (Magyarország) \\ Ráthonyi-Ódor Kinga (Ph.D.) \\ Debreceni Egyetem (Magyarország) \\ Pfau Christa (Ph.D.) \\ Debreceni Egyetem (Magyarország) \\ Szerző e-mail címe: \\ ...és további két anonim lektor
}

Szerdahelyi Z. (2020). Szubjektív egészségérzet és a fizikai aktivitás kapcsolatának vizsgálata középiskolások körében. Különleges Bánásmód, 6. (3). 51-64. DOI 10.18458/KB.2020.3.51

\begin{abstract}
Absztrakt
Egészségi állapotunk megítélésének számos módszere alakult ki a tudományos ismeretek bővülésével párhuzamosan. Az orvostudomány objektív módszerekkel, mérhetô változókkal írja le egészségi állapotunkat. Természetesen nekünk is van képünk a saját egészségi állapotunkról, mely minden szubjektivitása ellenére jó indikátora a testi-lelki folyamatainknak. Az egészségérzetünk hiteles tükre lehet az egészségi állapotunknak, mely közvetlenül és közvetetten is kihat a munkahelyi/iskolai teljesítményünkre. A fizikai aktivitás növekedésének az egészségre gyakorolt jótékony hatásairól folyamatosan bővülő ismeretekkel rendelkezünk, hatásmechanizmusát számtalan aspektusból értelmezhetjük. A középiskolás korosztály egészségi állapotának és fizikai aktivitásának vizsgálata hasznos információkat hordoz az egyén, a szülők és az oktatás területén (oktatáspolitikusok és pedagógusok) dolgozók számára. Jelen kutatás során a fizikai aktivitás (WHO ajánláshoz viszonyított) szintje és a középiskolások egészségérzete, iskolai teljesítménye, valamint a különböző emocionális tényezők megjelenése közti kapcsolatot vizsgálatára került sor, kiegészítve a 14-18 éves korosztály mozgással kapcsolatos motivációs hátterének tanulmányozásával. Az elemzés során szignifikáns kapcsolat jelent meg a fizikai aktivitás magas szintje és az egészségérzethez tartozó számszerűsített érték magas értéke között. Az iskolai teljesítmény és a fizikai aktivitás szintje között nem találtunk szignifikáns összefüggést. Az emocionális tényezők között szignifikáns kapcsolatot tapasztaltunk a boldogság, életkedv, energikusság, valamint a szomorúság és a fáradtság kategóriák fizikai aktivitással történő összehasonlítása során. A mozgásos motívumok között kiemelkedő helyet foglal el a fizikai állapot javítása, és egyértelmúen elutasító ez a korosztály a másoknak való megfeleléssel szemben. Szintén tanulságos a testi nevelés területén dolgozók számára, hogy a mozgás élményszerúsége meghatározó a korosztály tagjai számára.
\end{abstract}

Kulcsszavak: szubjektív egészség, fizikai aktivitás, középiskolai tanulók, emocionális tényezők, iskolai teljesítmény, motiváció

Diszciplína: pedagógia 


\begin{abstract}
RESEARCH ON THE RELATION BETWEEN THE SUBJECTIVE SENSE OF HEALTH AND PHYSICAL ACTIVITY AMONG SECONDARY SCHOOL STUDENTS
\end{abstract}

A number of methods have evolved for assessing our health in parallel with the expansion of scientific knowledge. Medicine describes our health by objective methods and measurable variables. Of course, we also have an image of our own state of health, which, for all its subjectivity, is a good indicator of our physical and mental processes. Our sense of health can be a genuine reflection of our state of health, which directly and indirectly affects our professional/academic performance. We have a constantly expanding knowledge of the beneficial effects of the increase in physical activity on health, and its mechanism of action can be interpreted from a number of aspects. The examination of the health and physical activity of the secondary school age group provides useful information for individuals, parents and those working in the field of education (education policy makers and educators). In this research, we examined the relationship between the level of physical activity (relative to the recommendations of WHO) and the sense of health of high school students, their school performance, and the appearance of various emotional factors. Then we complemented it with a study of the motivational background for those aged 14 to 18. During the analysis, we identified a significant link between high levels of physical activity and the high quantified value associated with the sense of health. We found no significant correlation between academic performance and physical activity levels. We experienced a significant relationship between emotional factors when comparing the categories of happiness, mood, energy, as well as sadness and fatigue with physical activity. Among the motivators for exercise, the improvement of physical condition is prominent, and this age group clearly rejects expectations of others. It is also instructive for those working in the field of physical education that the experience of exercise is critical for members of the age group.

Keywords: subjective health, physical activity, secondary school students, emotional factors, academic performance, motivation

Discipline: pedagogy

A fiatalok egészségi állapotának ismerete és javítása kulcsfontosságú terület a politikai döntéshozók, az egészségügyi szakemberek, a testi neveléssel foglalkozó szakemberek, illetve az érintett korosztály tagjai szempontjából egyaránt. A fiatalok egészségi állapotának magasabb szintre emelése stratégiai fontosságú az egyén, illetve a társadalmi-gazdasági mikro- és makrokörnyezete szempontjából. Az egészséges életmódhoz (mozgás, táplálkozás, mentális egyensúly) kapcsolódó pozitív attitűdök megerôsítése hosszútávú befektetésként is felfogható. Az időben, és megfelelő eszkö-zökkel/módszerekkel megalapozott egészség -befektetés egyéni, vállalati és nemzetgazdasági szinten is bőséges ,profitot termel”. A 14-18 éves fiatalok a közeljövő munkavállalói és családalapítói lesznek, ezért sem mindegy, hogy mekkora „egészségtőkét” halmoznak fel.

Az egészség és a rendszeres testmozgás között meglévő pozitív irányú kapcsolat régóta ismert tény. A neveléselmélet területének egybehangzó véleményét Bábosik $(2004,12$.) fogalmazta meg: „az egészség fenntartását szolgáló magatartásformák közül mindenekelőtt a mozgást kell kiemelni”.

A mindennapos testnevelés bevezetésétől (2012), illetve az ahhoz kapcsolódó paradigmaváltástól a 
tanulók fizikai aktivitásának növekedését, illetve a motorikus képességek, valamint a kardiorespiratorikus rendszer fejlődését várták a döntéshozók. Ezek a várako-zások részben beigazolódtak: a tanulók állóképessége, szív- és keringési rendszere javult, de az elhízás elleni küzdelemben egyelőre nem sikerült áttörést elérni. Megjegyzendő, hogy utóbbi területen a táplálkozás szerepe legalább akkora, mint a testmozgásé. Általános javulás az obesitas és az azzal szoros összefüggésben álló metabolikus szindróma területén leginkább az egészséges életmóddal kapcsolatos intézkedések holisztikus jellegének erősítésétől várható, mellyel párhuzamosan a szülői minta és a fogyasztási szokások változása is elengedhetetlen. Jelen kutatásban szerettük volna megtudni, hogy Hajdúböszörmény középiskolai tanulói esetében milyen kapcsolat mutatható ki, a fizikai aktivitásuk szintje és saját egészségi állapotuk megítélése között. Szeretnénk igazolni - a hajdúböszörményi középiskolásokra vonatkoztatva - a fizikai aktivitás egészségérzetet (és egyben egészséget) pozitívan befolyásoló hatását. Az aktivitás és az iskolai teljesítmény közti szoros kapcsolat elemzése tovább erôsítheti a pedagógusokban, a politikai döntéshozókban és természetesen a tanulókban a testmozgással kapcsolatos pozitív attitűdöket.

A fizikai aktivitás összetett hatásmechanizmusának alaposabb ismerete eredményesebbé és hatékonyabbá teheti a preventív jellegű, rendszeres testmozgást ösztönző programok megvalósítását. A kutatási eredményeket megosztva a településen tanító pedagógusokkal, nőhet az összehangolt kezdeményezések száma, melyek a szabadidősport népszerűbbé válásának folyamatát erôsíthetik.

\section{Elméleti háttér}

A fizikai aktivitás szerves részét képezi a mindennapi cselekvéseinknek, egyúttal biztosítéka az egészségünk megőrzésének (Laczkó és Rétsági, 2015), helyreállításának és javításának, illetve a gyermekben és felnőttben egyaránt jelen lévő játékigény (Laczkó és Melczer, 2015) kielégítésének.

Az emberiség mozgással kapcsolatos attitűdjeit számos negatív hatás (közlekedési szokások, kényelmi szolgáltatások, okoskészülékek használata) érte az elmúlt évtizedekben, és ez a folyamat jelenleg is tart. Az ülő életmód (homo sedens) kedvezőtlen hatásai hatványozottan érvényesülnek. Az viszont nem egyértelmú, hogy az okoskészülékek nagyobb arányú használata mindig egyet jelent a kevesebb mozgásmennyiséggel (Németh, 2016). Bár a testmozgás pozitív hatásairól folyamatosan bővülő ismeretekkel rendelkezünk, a fizikai aktivitás általános szintje elmarad az egészség megőrzéséhez szükséges szinttől (Guthold, 2018). A testmozgás hiánya az Egészségügyi Világszervezet becslései szerint 1,9 millió halálesetet okoz évente világszerte, a fejlett országokban a fizikai inaktivitást tartják a halálozás 66,7\%-ért felelősnek. A rendszeres fizikai aktivitás egészséget kedvezően befolyásoló hatása leginkább a prevenció területén érvényesül, de a terápiás kezeléseknél és a rehabilitációban is fontos szerepet kap (Laczkó és Melczer, 2015).

A fizikai aktivitás, az egészség, valamint ezen két terület közti összefüggések vizsgálata a hazai és a nemzetközi tudományos élet érdeklődésének kiemelkedően fontos területévé vált. Az érdeklődés növekedésének hátterében a fizikai inaktivitás negatív következményeinek felismerése, illetve az egyén egészségtőkéjével kapcsolatos „befektetések” hasznának szám-szerűsítése áll (Grossmann, 1972). Könnyen beláthatjuk, hogy mennyire fontos a középiskolai korosztály tagjainak egészségtőkeállománya (Pfau et al., 2018). Ha hosszútávon gondolkodunk, akkor számításba kell vennünk azt a mintaadó szerepet, melyet a mai fiatalok játszanak a következő generáció életében. A témával foglalkozó szakemberek rámutattak, hogy az egészségi állapot és a termelékenység között milyen erős kapcsolat áll fenn (Ács et al., 2011). Az egészségben eltöltött életévek számának növekedése, bi- 
zonyos mértékben a képzett munkaerő elégtelen mennyiségének negatív hatásait is ellensúlyozhatja.

A különböző típusú betegségek (szív- és érrendszeri-, daganatos-, mozgásszervi- és pszichés megbetegedések, a cukorbetegség és a kóros elhízás) kialakulásában az egyik fó kockázati tényező a fizikai aktivitás alacsony szintje (Apor, 2012). Az aktivitás növelése, a szabadidősport jelentőségének hangsúlyozása (Földesiné, 2009), és az ezzel kapcsolatos állami támogatások rendszerének kibővítésének érdekében jelentős intézkedések történtek (Laczkó és Rétsági, 2015), ennek ellenére az egészségügyi mutatók továbbra is lesújtó képet mutatnak (ELEF, OECD, EU jelentések). A civilizációs betegségként is említett mozgásszegény életmód (Soós et al., 2011) negatív egészségügyi következményeivel kapcsolatban folyamatosan bővülő szakirodalom áll rendelkezésünkre. Ezen munkák közös vonása (Gabnai et al., 2018), hogy az inaktivitásból származó terheket a gazdaság, a társadalom több szintjén is azonosítják (Chenoweth, 2005).

A 14-18 éves korosztály abban a „szerencsés” helyzetben van, hogy a különböző mozgásformák elsajátításának és rendszeres gyakorlásának útjába kevesebb akadályt gördítenek az életkor növekedé sével természetesen kialakuló korlátok (Hamar, 2005). Az egyre bővülő mozgásos lehetőségek közül (Halmai és Németh, 2011) emocionális és racionális érvek mentén választanak a fiatalok. A tartós motiváció kialakulása a két komponens együttes hatásától várható. A pedagógusoknak központi szerepe lehet a fizikai aktivitás változása által kiváltott hatásmechanizmus (fittség, jóllét, arousal-szint szabályozás), diákok felé történő közvetítésében (Csányi, 2010). Egy 2014-es vizsgálat (Boronyai et al., 2014) megállapította, hogy a 1418 éves korosztály megítélése szerint a testnevelőknek csak negyede (!) fordít figyelmet a fizikai aktivitás és egészség kapcsolatának hangsúlyozására, és csak harmada kezeli kiemelt szempontként a foglalkozások élményközpontúságát. Fiziológiás hatás szerint is érdemes megválasztani a testgyakorlatokat, figyelembe véve a jogszabályi hátteret (NAT, kerettanterv). Az eddigi kutatások igazolták, hogy a serdülő populációban a nagy intenzitású aerob testmozgás pozitív hatással van a jóllétre és a stressz-szint csökkentésére is. (Norris et al., 1992)

A középiskolás korú tanulók fizikai aktivitását több tényező (1. ábra) együttes hatása határozza meg (Konczos és Szakály, 2007; Ember, 2018).

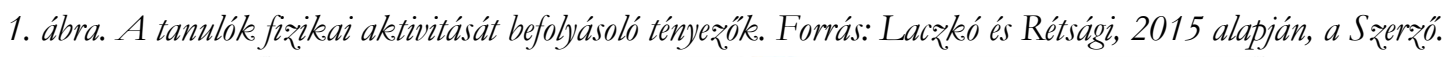

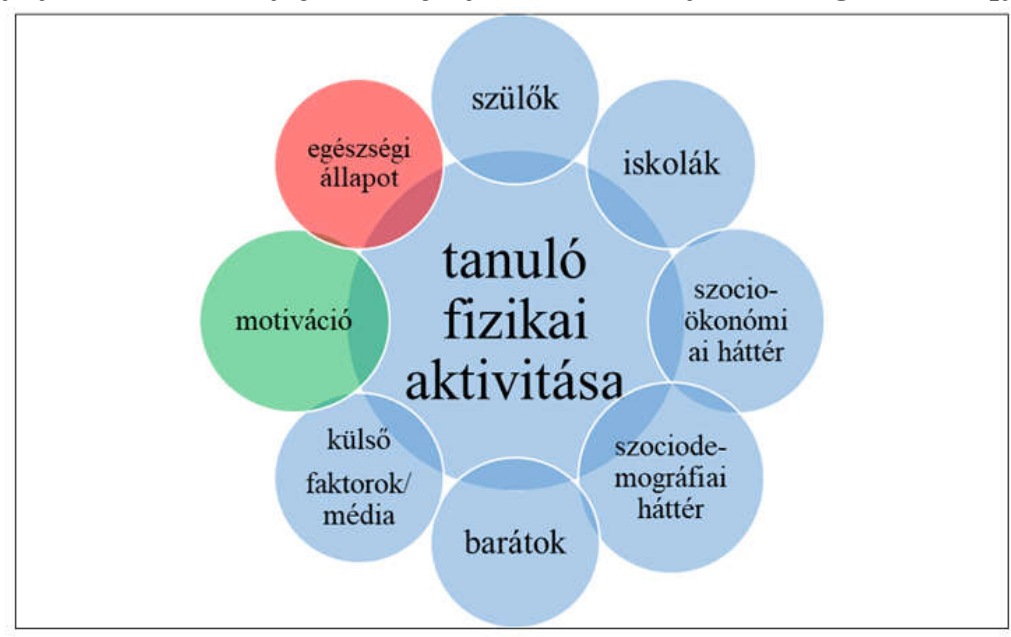


A szülői minta és az oktató-nevelő intézmények (Révész et al., 2014) mellett a baráti kapcsolatok és az egyéb külső faktorok (média, közösségi portálok), valamint a szociodemográfiai és szocioökonómiai háttér és a motivációs szint (Pikó et al., 2004) is befolyásolja a fiatalok testmozgással kapcsolatos attitúdjeit. Különösen fontos az a belső kész-tetést (általános aktivitás drive), amely azzal a ténnyel áll szoros összefüggésben, hogy a mozgás lételemünk.

Az előbb felsorolt tényezők, egyénre gyakorolt hatásának vizsgálata további kutatások felé vezet minket. A fizikai aktivitás és az objektív egészségi állapot közti kapcsolatok kutatása számos összefüggést tárt fel (Pluhár et al., 2004; Lampek és Kivés, 2014), melyek közös vonása, hogy az aktivitási szint növekedésével számos krónikus betegség (szív- és érrendszeri, az anyagcserét kórosan befolyásoló, pszichés, daganatos, mozgásszervrendszert érintő betegségek) kialakulási valószínűsége csökkenthető. A Nemzeti Népegészségügyi Központ, koronavírus-járvánnyal (COVID-19) kapcsolatos hivatalos tájékoztatója (2020. március 14.) is első helyen hívta fel a figyelmet a fizikai aktivitás fontosságára, mely szerint: „A rendszeres fizikai aktivitásnak gyulladáscsökkentő hatása van, befolyásolja a fehérvérsejtek, azon belül a vírusok elenni védelemben szerepet játszó sejtek aktivitását, fokozza számos gyulladáscsökkentő anyag termelődését" (Nemzeti Népegészségügyi Központ, 2020. 03. 14.)

Bár számos tényező befolyásolja az egészségi állapotunkat, a legfontosabb tényezó maga, az egyén (Makai, 2019)(2.ábra). A szubjektív egészségi állapot (egészségérzet) és a fizikai aktivitás kapcsolatának vizsgálata sem újkeletủ (Barabásné és Keresztes, 2017).

Ezek alapján kijelenthetjük, hogy azok, akiknek a mozgásmennyisége eléri/meghaladja a WHO ajánlásában (WHO, 2010) megfogalmazott mértéket (napi 60 perc mérsékelten intenzív vagy intenzív mozgás), a saját egészségi állapotukat is jobbnak itélik meg, mint azok, akiknek az aktivitási szintje elmarad az ajánlásoktól.

Az is bizonyított tény (Tahin et al., 2000), hogy a saját egészségünkrôl alkotott kép az orvosi vizsgálatokkal igazolható egészségi állapottal erősen korrelál, pozitív irányban. Az egészségi állapot leírására objektív és szubjektív módszerek állnak rendelkezésünkre.

Előbbi az egészségügy területén dolgozó szakemberek kompetenciája, utóbbival kapcsolatban pedig a vizsgált egyén önbevallásán alapuló vizsgálat során nyerhet értékes információkat a kutató.

Hazánk, az egészségi állapotunk megítélésben, az utolsó előtti helyen állt az Európai Unió tagországai között az ezredforduló után. (Tokajiné és tsai., 2011). Látszólag a szubjektív megítélés megismerése feleslegesnek tűnhet, ha egyszer objektív tényezőket is tudunk vizsgálni. Ennek ellentmondanak azok a tudományos eredmények (Dahlgren és Whitehead, 1991), melyek szerint az egészség megítélését befolyásolja az egyén társadalmi, gazdasági, kulturális helyzete (pl. iskolai végzettsége, foglalkozása, jövedelme, lakóhelye), életkora. Minél idősebb a vizsgált korosztály, annál kevesebben tartják jónak, és annál többen rossznak az egészségi állapotukat. Ezt a képet tovább árnyalja, ha a nemek közti különbséget is figyelembe vesszük. Az ötévente elvégzett Európai Lakossági Egészség-felmérés $(2009,2014,2019)$ eredményei azt mutatják, hogy a férfiak kedvezőbben itélik meg saját egészségi állapotukat, mint a nők. A módszert, szubjektivitásából adódó torzító hatásai ellenére, a nemzetközi gyakorlatban is ismétlődően alkalmazzák a különböző egész-ségfelmérések (HBSC Health Behaviour in School-Aged Children) készítésekor. Egyszerű, gyors módszer, és az eredmények megbízhatóan tükrözik az egyén valós egészségi állapotát. Természetesen azt is figyelembe kell vennünk, hogy az egészségi állapot megítélésekor nemcsak a tényleges betegségek (vagy azok hiánya) határozzák meg véleményünket, hanem 
egyéb hatások is befolyásolhatják a válaszadót, mint például az iskolázottság, anyagi helyzet, lakóhely, pszichés állapot, elégedettség-érzés, nemzeti-etnikai hovatartozás. Elég, ha az egyes nemzetek autosztereotípiáival kapcsolatos közvélekedésre gondolunk; a magyarság és a kollektív pesszimizmus azonosítása (Kopp és Skrabski, 2009).

A 2020-ban kialakult pandémia jelentősen befolyásolhatja a diákok véleményét, saját egészségi állapotuk szintjével kapcsolatban. A szubjektív egészségi állapot kérdésköre pedig elvezet minket a szubjektív jóllét (elégedettség, életminőség) témaköréhez (Költő és Kökönyei, 2011). Hamvai és Pikó $(2009,56$.) szerint: „a szubjektív jóllét egyszerűen a pozitív érzelmek túlsúlyát jelenti a negatív érzésekkel szemben.” A szubjektív jóllét és a szubjektív egészségérzet közötti kapcsolat kétirányú. Hosszútávon mindkét irányban erôs a kölcsönhatás (endogenitás), rövid-távon viszont inkább jellemzi az egyirányúság (exogenitás), azaz a pozitív egészségérzet pozi-tívan befolyásolja a jól lét, egyén általi megítélését. Ha ezt a gondolatmenetet folytatjuk, akkor eljuthatunk az Európai Unió által is megfogalmazott megállapításhoz, miszerint a magasabb szintű életminőség a nagyobb gazdasági növekedés irányába mutat (Európa 2020 Stratégia), vagyis a fizikai aktivitás növekedése fontos előfeltétele a tartós gazdasági növekedésnek.

A 2. ábra vázolja az előzőekben felsorolt tényezők és a fizikai aktivitás kapcsolatrendszerét, de fontos kiegészíteni, hogy ezek nemcsak a fizikai aktivitással állnak kétirányú kapcsolatban, hanem egymással is.

\section{Kutatás}

A vizsgálat részét képezte a fizikai aktivitás és az iskolai teljesítmény közötti szubjektív kapcsolat jellegének és erôsségének feltárása. A fizikai aktivitás és az egyén érzelmi tényezői közötti pozitív és negatív kapcsolatok feltérképezése a testi-lelkiszellemi ,jóllét” állapotának kérdéskörét érintette.

2. ábra: A fizikai aktivitás, az egészség és a jóllét kapcsolata Forrás: Makai, 2019 alapján a Szerzố.

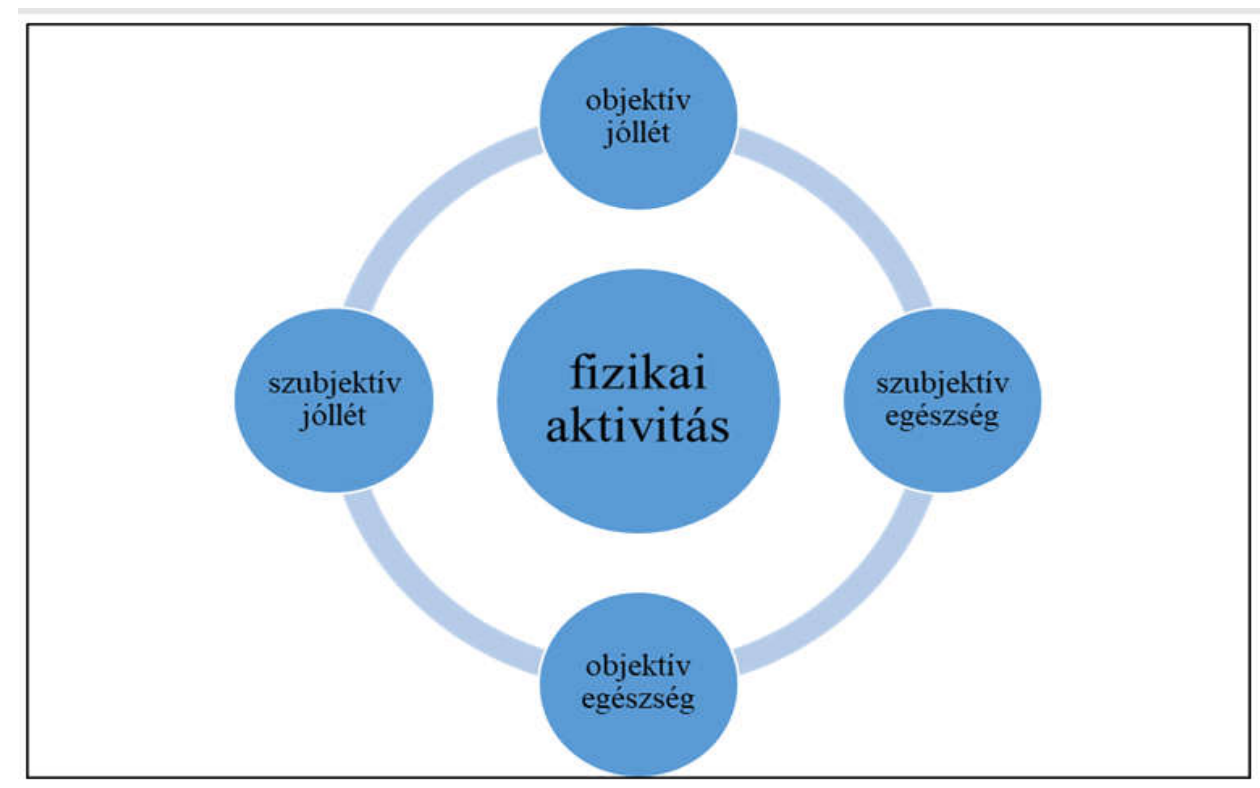


Feltárásra került a betegségben eltöltött napok és a fizikai aktivitás közti alapvető összefüggést. Arra is kerestük a választ, hogy az aktivitás, diákok általi megitélése hogyan változik a szociális távolság függvényében, vagyis a szubjektív megítélést befolyásoló tényezők szerepét is vizsgáltuk. A kutatásra 2020 tavaszán került sor Hajdúböszörményben. Jelen tanulmány egy nagyobb kutatás része, melynek során a hajdúböszörményi lakosság körében végzett, (korra és nemre) reprezentatív vizsgálattal kívánjuk feltérképzeni és modellezni a különböző generációk fizikai aktivitásának főbb összetevőit. Az 1. táblázat foglalja össze a jelenlegi kutatás során vizsgált területeket a fizikai aktivitással összefüggésben.

1.táblázat. A kutatás során viazsgált terïletek. Forrás: a Szer:ö.

egészség (tanulók általános és aktuális egészségi állapota, tartós betegség típusai, egészségi állapotban bekövetkező változás)

emocionális jellemzők (idegesség, életkedv, letargia, nyugalom, energikusság, szomorúság, kimerültség, boldogság, fáradtság)

szubjektív munkahelyi/iskolai teljesítmény

\section{Hipotézisek}

1. Azon tanulók esetében, akiknek a fizikai aktivitás szintje eléri/meghaladja a WHO ajánlását, azok egészségi állapotukat is szignifikánsan jobbnak tartják, mint azon tanulók, akik az egészségmegőrzést jelentő aktivitási szintet nem érik el.

2. Az iskolai teljesítmény megítélése és a fizikai aktivitás szintje között szignifikáns kapcsolat mutatható ki, mely pozitív irányú.
3. A tanulók emocionális tényezôi közül a pozitív összetevők szignifikánsan nagyobb mértékben jelennek meg azok esetében, akiknek a fizikai aktivitási szintje eléri/meghaladja a WHO, testmozgással kapcsolatos ajánlását.

4. A válaszadók mozgással kapcsolatos motivációi között meghatározó szerepet kapnak az egészséggel kapcsolatos tényezők.

\section{Anyag és módszer}

A vizsgálat alapját Hajdúböszörmény egyetlen gimnáziumának (Bocskai István Gimnázium) helyi illetőségú tanulói körében végzett adatgyüijtés képezi. A 14-18 év közötti korosztály vizsgálatára az intézményvezetôk, illetve a szülők hozzájárulásával került sor. A minta nagysága $\mathrm{N}=302$, mivel a kiosztott 360 kérdőívből kilenc darab nem volt értékelhető. A minta 68,2 százaléka lány, 31,2 százaléka fiú. A különböző életkorú tanulók százalékos megoszlása is megfelel az alapsokaságnál tapasztalt adatoknak, így a minta reprezentatívnak minősül nemre és korra vonatkoztatva. Az átlagéletkor: 16,9 év. A megkérdezettek mindegyike nappali tagozatos középiskolai tanuló.

A kutatás során önkitöltős kérdôivet alkalmaztunk. A kérdôív 22 itemből áll, melynek összeállításakor felhasználtam nemzetközileg validált kérdőíveket (IPAQ- International Physical Activity Questionnaire - short form, PALMS - Physical Activity and Leisure Motivation Scale, EQ-5D - EuroQoL skála - European Quality of Life, SF-36 36- item Short Form Health Survey), valamint saját szerkesztésú kérdéseket. A kérdések a szociodemográfiai adatokon túl vizsgálják az egyén általános és aktuális egészségi állapotával kapcsolatos megítélését, a munkavégzéssel járó fizikai aktivitást, az otthoni és a közlekedés során mutatott fizikai aktivitást, a tanulók saját iskolai teljesítményének szintjét, a tanulók emocionális jellemzőit.

A kérdések között megtalálhatóak a nyílt végú, illetve zárt végú kérdések egyaránt. Több kérdés 
esetében ötfokozatú Likert-skálán adható meg a válaszadóra jellemző érték. Az adatok elemzéséhez SPSS 22.0 statisztikai programot használtunk. A leíró statisztikai eredményeken túl kereszttáblaelemzést és khí-négyzet próbát végeztünk, értelmezve az asszociációs és korrelációs együtthatókat.

\section{Eredmények}

A kérdőívben 1-100-ig terjedő skálán kellett értékelni a megkérdezetteknek saját egészségi állapotukat (1=lehető legrosszabb egészségi állapot, $100=$ lehető legjobb egészségi állapot). Életkor alapján öt kategória kialakítására került sor (1-20, 20-40, 41-60, 61-80, 81-100), és az egyes kategóriákra adott válaszok és fizikai aktivitás WHO ajánláshoz (napi 60 perc mérsékelten intenzív/intenzív testmozgás) viszonyított szintje között kerestük az összefüggéseket (3.ábra).
Az egészségi állapot esetében 1-20 közötti értéket adott meg a válaszadók 0,7 százaléka, 21-40 közöttit a 4,6 százaléka, 41-60 közöttit a 8,6 százaléka, 61-80 közöttit a 30,5 százaléka és 81-100 közöttit az 55,6 százaléka. A diákok több, mint 85 százaléka jónak vagy kiválónak minősítette az egészségi állapotát. A válaszadók 21, $9 \%$-a 90-es értéket jelölte meg (leggyakoribb). 17,8\%-uk 95\%fölötti értéket jelölt meg.

A fizikai aktivitást tekintve, a tanulók 35,1 százaléka tartja úgy, hogy teljesíti a fizikai aktivitásra vonatkozó ajánlásokat. Ha a „nagymértékben” és a „teljes mértékben” válaszait együttesen nézzük, akkor ez az arány 57,6 százalék, mely pozitívnak tekinthetô, ha valóban teljesül.

A kereszttábla-elemzés során szignifikáns összefüggés mutatható ki az egészségi állapot megítélése és a fizikai aktivitás szintje között $(p=0,031)$. A gamma értéke 0,414 , mely közepesen erős kapcso-

3.ábra. Középiskolai diákok egészségi állapot értékelése. Forrás: Sžrzọ.

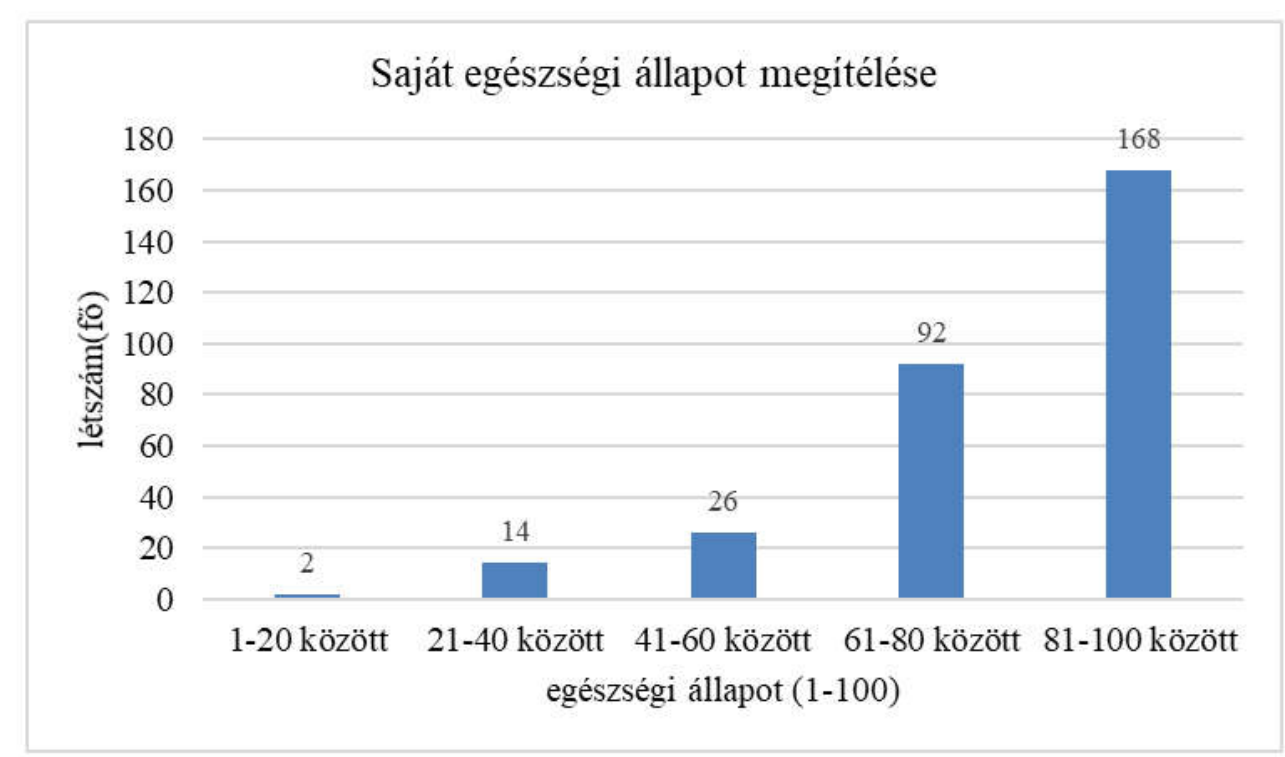


latot jelez, a korrelációs együttható $(r=0,302)$ pedig gyenge-közepes pozitív kapcsolatot erősít meg.

Ez a mintánkra vonatkoztatva azt jelenti, hogy azok a tanulók, akik teljesítik/túlteljesítik a WHO ajánlásban foglaltakat, azok szignifikánsan jobbnak ítélik meg saját egészségi állapotukat.

A kereszttábla-elemzés alapján nem mutatható ki szignifikáns kapcsolat a tanulók iskolai teljesítményének szubjektív megitélése (alulteljesít átlagosan teljesít - átlagon felül teljesít) és a fizikai aktivitás szintje között. Az viszont jól látható (4. ábra), hogy a WHO ajánlást teljesítő diákok száma az átlagos és az átlagon felüli teljesítmény esetében magasabb, mint azoknál, akik mozgásmennyisége nem éri el az ajánlott szintet.

Az arányokat tekintve a legnagyobb különbség az átlagon felüli iskolai teljesítmény esetében figyelhetô meg (18:36). Így bizonyos erôsségú összefüggés feltételezhető a két vizsgált terület között. A későbbiekben érdemes lenne a szám-szerûsített iskolai eredményeket (tanulmányi átlagok) a fizikai aktivitásra vonatkozó változókkal vizsgálni.
$\mathrm{Az}$ emocionális tényezőkre adott válaszokból (5.ábra) kiderül, hogy a kilenc tényezőbool (négy pozitív, négy negatív és egy semleges válasz) hat átlaga haladja meg a 3,00 értéket (közepes/ nagy/teljes mérték), melyek közül egy semleges (fáradtság), egy negatív (kimerültség) és négy pozitív faktor (életkedv, nyugalom/békés állapot, energikusság, boldogság).

A kimerültség és fáradtság kategóriák esetében elképzelhető, hogy a tanulók a kettő fogalom közti jelentésbeli különbségeket figyelmen kívül hagyták, és szinonim kifejezésekként alkalmazták.

A legmagasabb értéket a "fáradt vagyok” és a „boldog vagyok” kategória mutatja. Ebben az életkorban gyors (gyakran viharos) testi-lelkiszellemi átalakuláson mennek keresztül a fiatalok. A fáradtságérzet természetes-nek mondható, és örömteli tény, hogy emellett a boldogság érzete a meghatározó.

4. ábra. Iskolai teljesitmény és fizikai aktivitás kapcsolata. Forrás: Szerzőo.

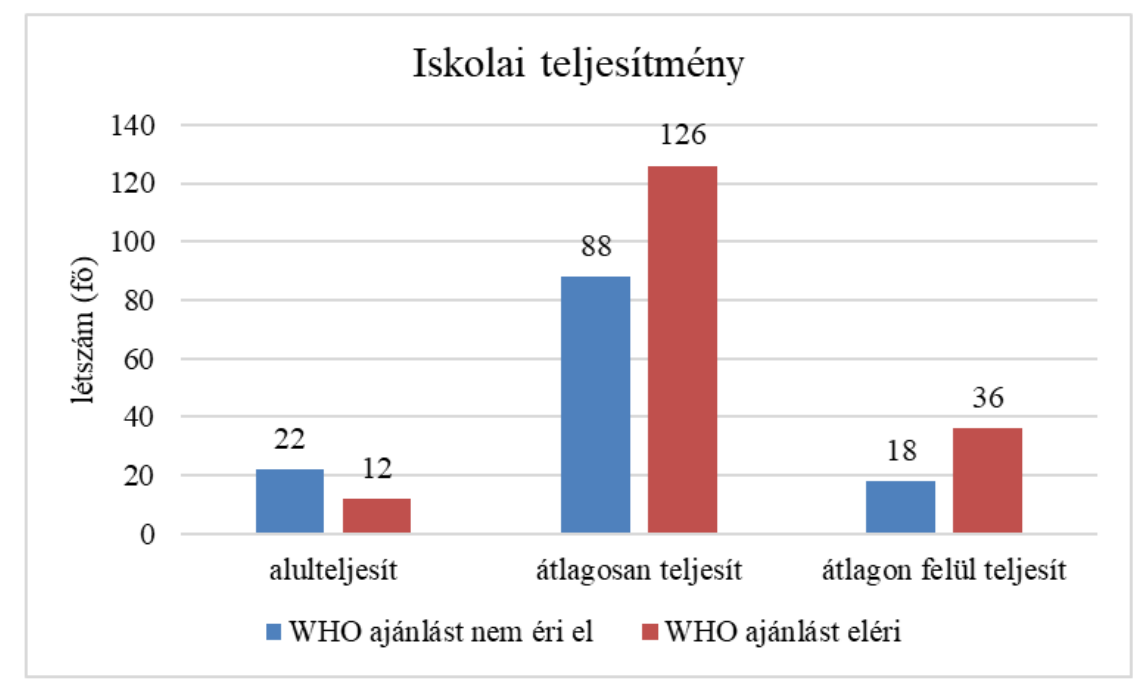


Ha az egyes kategóriákra adott válaszok értékének szórását vizsgáljuk, kiderül, hogy a leginkább a deprimáltságra adott válaszok esetében értettek egyet a tanulók (SD=0,92), szerencsére egy alacsony átlagértékkel párosítva $(\mathrm{M}=1,68)$, mely a lehetséges öt válaszlehetőség közül a „,kis mértékben" kategóriával mutat egyezést. A legnagyobb véleménykülönbség a „kimerült voltam” esetében tapasztalható $(\mathrm{SD}=1,21)$, a harmadik legmagasabb átlaggal $(\mathrm{M}=3,32)$.

Érdemes megvizsgálni, hogy mely kategóriák esetében választották a legnagyobb arányban a teljes mértékben jellemző választ. A válaszadók 31,8 százaléka a „fáradt voltam”, 23,8 százaléka pedig a „boldog voltam” tényezők esetében jelölte a maximális értéket. Ez utalhat szellemi és fizikai fáradtságra egyaránt, de mindenképp pozitív eredmény, hogy ezzel együtt a diákok csaknem negyede teljes mértékben boldog. Ha ehhez még hozzávesszük a nagymértékben lehetőséget választókat is, akkor mindkét kategória esetében 60 százalék fölötti értéket kapunk, vagyis a tanulók többsége egyszerre fáradt és boldog. Ennek az egyik legfőbb magyarázatát az iskolatípusban kereshetjük. A gimnáziumban tanuló diákok között túlnyomó többségben vannak azok, akik a középiskolai tanulmányaik befejezése után a felsőoktatásban kívánnak továbbtanulni. Ehhez jó tanulmányi eredményre van szükség, melynek elérése kitartó munkát feltételez, amely fárasztó is lehet.

A fizikai fáradtságot pedig a rendszeres, tanórán kívüli testmozgás magyarázhatja, melynek gyökerei a támogató szülői háttérben (példamutatás, anyagi támogatás) és az aktív baráti környezetben keresendők.

Az egyes kategóriákra adott válaszokat és a fizikai aktivitás szintjét kereszttábla-elemzéssel vizsgáltuk. A „tele voltam életkedvvel” kategória esetében szignifikáns kapcsolat mutatható ki a fizikai aktivitással összefüggésben ( $p=0,1)$. A gamma értéke (0,353) pozitív irányú kapcsolatot jelez. A korrelációs együttható értéke alapján $(\mathrm{r}=0,277)$ gyenge pozitív kapcsolatra következtethetünk. A ,tele voltam energiával" kategória esetében hasonló szignifikáns kapcsolat mutatható ki, mint a „tele voltam életkedvvel" (a két fogalom alapján kölcsönös asszociációt feltételezek) a fizikai aktivitással összefüggésben $(p=0,11)$.

5. ábra. Emocionális tényezốk megjelenése a diákok körében. Forrás: Szerzőó.

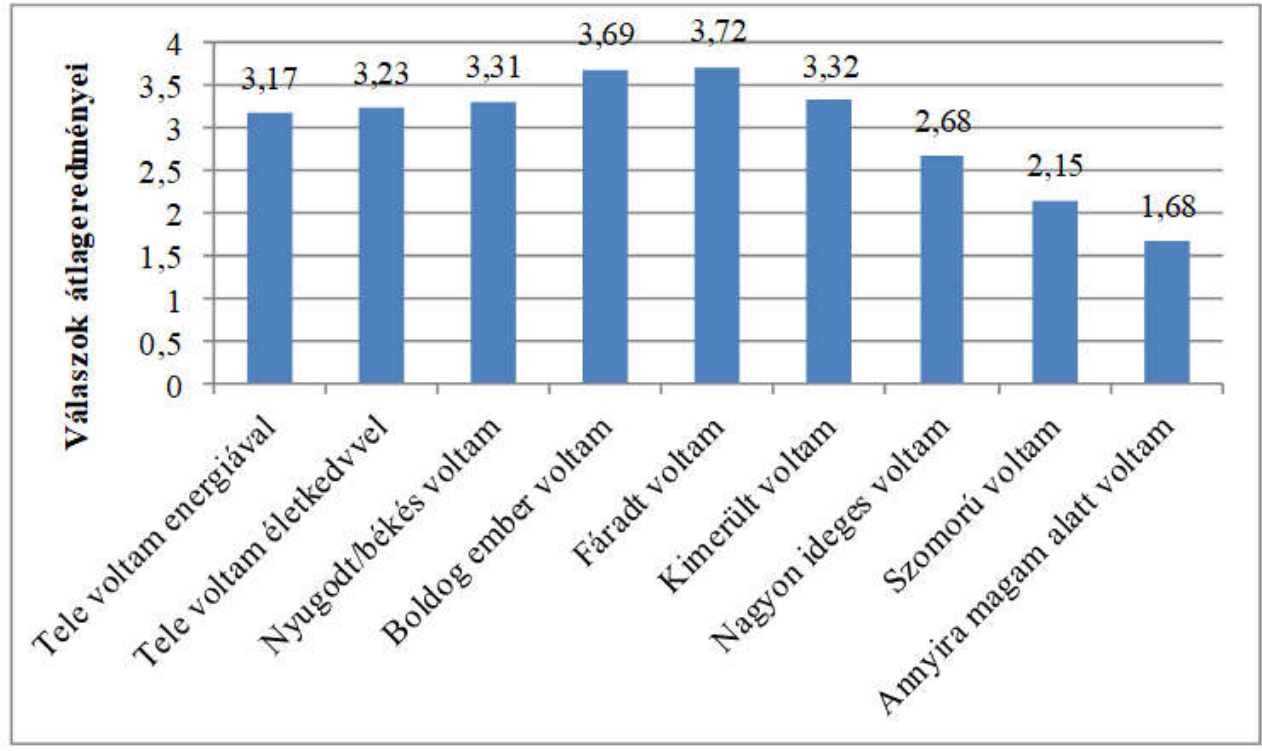


A gamma értéke $(0,409)$ itt is pozitív irányú kapcsolatra utal. A korrelációs együttható értéke alapján $(\mathrm{r}=0,353)$ szintén gyenge pozitív kapcsolatra következtethetünk. A „,boldog ember voltam" kategória esetében is szignifikáns kapcsolat mutatható ki $(\mathrm{p}=0,41)$. A gamma értéke $(0,337)$ pozitív irányú kapcsolatot mutat. A korrelációs együttható értéke $(\mathrm{r}=0,267)$ gyenge pozitív kapcsolatként értelmezhető.

Közös vonása ezeknek a faktoroknak, hogy a fizikai aktivitás növekedésével párhuzamosan a pozitív érzelmi állapot stabilan jellemző a válaszadóra.

A pozitív töltetú válaszok után a negatív jelentéstartalommal bíró tényezőket vettük górcső alá. A „szomorú voltam” kategória esetében szignifikáns a kapcsolat $(p=0,003)$. A gamma értéke $(-0,318)$ negatív irányú kapcsolatot jelez. A korrelációs együttható értékéből ( $\mathrm{r}=-0,277)$ gyenge negatív kapcsolatra következtethetünk. Ez azt jelenti, hogy a fizikai aktivitás szintjének növekedésével együtt a szomorúság „mértéke” csökkenő értékeket mutat. A „fáradt voltam” kategória esetében szintén szignifikáns kapcsolat mutatható ki a fizikai aktivitással összefüggésben ( $\mathrm{p}=0,07)$. A gamma értéke $(-0,276)$, ez is negatív irányú kapcsolatot bizonyít. A korrelációs együttható értéke $(r=-0,235)$ alapján gyenge negatív kapcsolatra következtethetünk. Ez azt jelenti, hogy a fizikai aktivitás szintjének növekedésével együtt a fáradtság csökkenő értékeket mutat. Ez a látszólagos ellentmondás azzal oldható fel, hogy a megkérdezettek csaknem kétharmada (63,6 százalék) szabadidősport-tevékenységet folytat, mely nem terheli túl a szervezetet. A fáradtság érzése átmeneti lehet, míg a mozgásos tevékenység által kiváltott öröm- és boldogságérzet tartós marad. Ehhez társulhat még az aktivitás (fizikai-szellemi) ellenálló-képességre gyakorolt pozitív hatása is.

A következő kategóriák esetében nincs szignifikáns kapcsolat: „nagyon ideges voltam, annyira magam alatt voltam, nyugodt/békés voltam, kimerült voltam".
A tanulók mozgásos motívumait tekintve feltűnő a fizikai állapot javításának fontossága $(M=4,47)$, a többi tényező 4,00 alatti értéket mutat. Ez a legfontosabb a válaszadók számára. Ebben az életkorban a morfológiai átalakulás egy meghatározó időszakát élik a fiatalok, melyhez társul a külső környezet (média) által sugallt ideális testkép. A társas kapcsolatok kialakításában/megőrzésében is fontos szerepet tulajdonítanak a mozgásnak. Itt elsősorban az együtt végzett mozgásos tevékenység kohéziós erejére, illetve a mozgás által kiváltott pozitív testi változásokra (izomhipertrófia) kell gondolni.

Az „Élvezet/élmény” magas értéke megerősíti azt a módszertani axiómát, mely a teljesítményorientáció helyébe az élményközpontúságot állítja. A diákoknak olyan mozgásformákkal kell megismerkedniük, melyek egyszerre hatnak a fizikai állapotra, és ezzel egyidőben örömszerzés eszközévé is válik. Ezeknek a feltételeknek a teljesülése esetén kölcsönös elégedettség alakul ki és erősödik meg a pedagógus és a diákok között.

A minta életévenként (15-19 év) kialakított csoportjaiban kereszttábla-elemzést végeztünk a motivációs faktorok és az életkor változása közti szignifikáns kapcsolatot keresve. Itt azonban nem mutatható ki ilyen jellegú kapcsolat, vagyis a mozgásos motívumok hatását tekintve homogénnek tekinthetjük a vizsgált mintát. Kivételt képez a „Vetélkedés/versengés”, ahol $\mathrm{p}=0,036$, az asszociációs együttható értéke 0,214 (Cramer's V), a korrelációs együttható pedig $\mathrm{r}=-0,097$, mely gyenge negatív kapcsolatot mutat. Utóbbiból arra következtethetünk, hogy az életkor növekedésével a kompetitív motívumok szerepe halványul. Ez is megfelel a korábbi kutatási eredményeinknek, mely szerint az egyetemi hallgatók között a versengésnek csökken a motiváló ereje. Az alacsony érték (közel a nullához) viszont azt jelzi, hogy ez a folyamat még a kezdeti fázisában tárul elénk. 


\section{Következtetések}

A vizsgálat eredményei túlnyomó részt igazolták az elôzetes feltevéseket. A középiskolai tanulók közül azok ítélték meg kedvezőbbnek az egészségi állapotukat, akik saját bevallásuk szerint a WHO ajánlásnak megfelelő mennyiséget mozognak. A tanulók csaknem kétharmada szabadidő-sportoló, melynek egészségérzetet és egészségi állapotot befolyásoló pozitív hatása ebben az esetben is bizonyítást nyert. Ez az eredmény is alátámasztja azt nézetet, miszerint a szabadidősporttal kapcsolatos lehetőségek körét bővíteni kell a lakosság egészségi állapotának javitása érdekében.

Szintén ebbe az irányba mutat a mozgásos motívumok feltérképezése és hatásuk vizsgálata is. A diákok számára az élményszerűség, a testi képességek fejlődése a meg-határozó a mozgás során, de számos egyéb faktort is figyelembe kell vennünk, mikor a 14-18 éves korosztály számára tervezünk/szervezünk mozgá-sos tevékenységet. Ez a munka kétirányú, de ideális esetben a két irány egymást kiegészíti.

A tanórán kívüli és a tanórai mozgás kölcsönhatása hosszú-távon határozhatja meg az egyén fizikai aktivitását. Az iskolai testnevelésben tanító szakembereknek be kell építeni a pedagógiai munkájukba (a didaktikai alapelvek megtartásával együtt) az élmény-központúság biztosítását és a motoros képességek fejlesztését. Ezzel egyidőben viszont csökkenteni kell a kompetitív összetevők szerepét, hiszen az eredmények egyértelmúen bizonyították, hogy a tanulók számára a másokkal való vetélkedés nem növeli, hanem inkább csökkenti a mozgással kapcsolatos ösztönző erôt.

Azt is figyelembe kell vennünk, hogy a fiatalok számára a társas kapcsolatok hálózatának építése, a külső megjelenés és a pszichés állapot javítása egyformán fontos szerepet kap, amikor döntenek a különböző mozgásformák között. A kutatási eredményekből egyértelmúen kitűnik, hogy a fiatalok számára fontos a saját egészségük megőrzése/fejlesztése, és tisztában vannak a rendszeres mozgás és az egészségi állapot közti erős okokozati kapcsolattal.

A kedvező sportolási arány (a tanulók háromnegyede szabadaidô- vagy versenysportoló) részben az ilyen iskolatípusban tanulók szociodemográfiai jellemzőivel magyarázható. Más iskolatípusban (szakgimnázium, szakközépiskola) végzett hasonló kutatások nagy valószínűséggel árnyalnák ezt a pozitív képet. A közoktatásban jogszabályok által meghatározott testnevelés területén kívánatos (és folyamatban lévő) megújulás hozzájárulhat a diákokban hagyományosan meglévő negatív attitűdök ellensúlyozásához, valamint a pedagógusokban rejlő kreativitás és innovatív képességek kibontakozásához.

$\mathrm{Az}$ is számszerűen megjelenő eredmény, hogy az iskolai teljesítmény és a fizikai aktivitás szintje között is van összefüggés, bár jelen esetben statisztikailag igazolható erősségút nem találtunk. A szakirodalmi eredményekkel összhangban állnak a teljesítményre vonatkozó következtetések, vagyis a WHO fizikai aktivitásra vonatkozó ajánlását teljesítő tanulók iskolai teljesítménye jobb, mint azoké, akik kevesebbet mozognak.

\section{Összegzés}

2020. március 16-tól digitális oktatási munkarend lépett életbe (1102/2020. sz. Kormány határozat) a közoktatási intézményekben is, mely alapvetôen megváltoztatta ebben az átmeneti idôszakban a tanulók sportolási szokásait (tanórák, edzések, osztály- és edzőtársak nélküli mozgás), mely akár a motivációs szint csökkenéséhez vezethetett, és az akarati tényezők maximális mozgósítását kívánta. A pedagógusoknak óriási szerepe lesz az elkövetkező idôszakban is abban, hogy a tanulói érdeklődést, motivációt megtartsák, helyreállítsák, illetve növeljék, az oktatói kreativitás kiteljesítésével egyidőben, a módszertani megújulás jegyében. A közösségi portálokon példamutató összefogást tanúsítanak a testi nevelés területén dolgozó szakemberek, 
melynek célja: a játékosság és élményközpontúság biztosításával fenntartani a fiatalok mozgáskedvét. A diák - szülő - intézmény - külső környezet kapcsolatrendszerének erősítésén és megszilárdításán kell dolgoznunk. Ez részben egyéni, részben össztársadalmi érdek, mind népegészségügyi, mind nemzetgazdasági szinten. Ez azonban alapvető szemléletváltást tesz szükségessé az érintettek részéról.

A publikáció elkészitését a „GINOP-2.3.2-15-201600062 Életminöség fejlesztése Kelet-Magyarországon: Táplálkozás-, teljesitménybiológiai és biotechnológiai experimentális kutatások és eszközajejlesztések a bumán megbetegedések megelózésére és kezelésére" projekt támogatta.

\section{Irodalom}

Ács Pongrác, Hécz Roland, Paár Dávid, Stocker Miklós (2011b): A fittség (m)értéke - A fizikai inaktivitás nemzetgazdasági terhei Magyarországon. Közgazdasági Szemle, 58. 689-708.

Apor Péter (2012): Testedzéssel a megbetegedések ellen. Magyar Tudomány, 173. 12.. 1470-1477.

Bábosik István (2004): Neveléselmélet. Budapest, Osiris Kiadó.

Barabásné Kárpáti Dóra, Keresztes Noémi (2017): Szubjektív jóllét a sportolási gyakoriság tükrében. Magyar Sporttudományi Szemle, 18 (69): 4-9.

Boronyai Zoltán, Vass Zoltán, Rétsági Erzsébet, Csányi Tamás és Révész László (2014): 14-18 éves tanulók attitűdje a testnevelés órával és a testnevelóvel kapcsolatban. Magyar Sporttudományi Szemle, 15 (58): 22-23.

Chenoweth, D. (2005): The Economic Costs of Physical Inactivity Obesity and Overweight In California Adults:Health care Workers' compensation, and lost productivity. Chenoweth \& Associates, Inc, New Bern, North Carolina.
Csányi Tamás (2010): A fizikai aktivitás és egészség fiatal korban. Egészrégfejlesztés. 51. (1-2):43-48.

Dahlgren, G. and M. Whitehead (1991): Policies and strategies to promote social equity in health. Stockholm: Institute for future studies

Ember Zsolt (2018): Serdülőkorúak egészségmagatartása a negatív életesemények, a társas támogatottság, valamint a protektív és kockázati magatartások vonatkozásában. Acta Medicinae et Sociologica, 9 (26): 21-44.

Földesiné Szabó Gyöngyi (2009): Szabadidősport életmód - sportpolitika. Hazai és nemzetközi tendenciák. In: Salga P. (szerk.) (2009): Útban a sportoló nemzet felé. Elvek és tények a magyar szabadidősportban. Budapest: Nemzeti Szabadidősport Szövetség, 17-28.

Gabnai Zoltán, Müller Anetta, Bács Zoltán, Bácsné Bába Éva (2018): A fizikai inaktivitás nemzetgazdasági terhei, Egészségfejlesztés 60 (1): 20-30.

Grossman, Michael (1972): The Demand for Health: A Theoretical and Empirical Investigation. Columbia University Press for the National Bureau of Economic Research, New York.

Guthold, Regina (2018): Worldwide trends in insufficient physical activity from 2001 to 2016: a pooled analysis of 358 population-based surveys with 1.9 million participants. The Lancet, 6 (10): 1077-1086. doi: 10.1016/S2214$\underline{109 X(18) 30357-7}$

Halmai Réka, Németh Ágnes. (2011): Fizikai aktivitás és szabadidős tevékenységek. In Németh Ágnes és Költő András (Szerk.): Serdülōkorú fiatalok egészsége és életmódja 2010. Az Iskoláskorú gyermekek egészségmagatartása címú, az Egészségügyi Világszervezettel együttműködésben zajló nemzetközi kutatás 2010. évi felméréséről készült nemzeti 8 jelentés.

Hamar Pál (2005): A rendszeres testedzés helye és szerepe a serdülőkorú lányok életvitelében. Új Pedagógiai S remle, 55(10): 68-75. 
Hamvai Csaba és Pikó Bettina (2009): Serdülők szubjektív jóllétét meghatározó társas tényezők a családban és az iskolában. Új Pedagógiai Szemle, 59(4): 30-42.

Konczos Csaba, Szakály Zsolt (2007): Az ifjúság fizikai aktivitásának jellemzői, az életstílus befolyásolása, a fizikai aktvitás tudatos alkalmazása. Magyar Sporttudományi Szemle, 8 (30): 3946.

Kopp Mária, Skrabski Árpád (2009): Magyar lelkiállapot az ezredforduló után. Távlatok: világnézet, lelkiség, kultúra, 19 (86): 32-52.

Költő András, Kökönyei Gyöngyi (2011): Szubjektív jóllét. In Németh Ágnes, Költő András. (Szerk.) Serdülőkorú fiatalok egészsége és életmódja - 2010. Országos Gyermekegészségügyi Intézet, 67-76.

Laczkó Tamás, Melczer Csaba (2015): Az egészségsport alapjai. Pécsi TE. Egészségtudományi Kar. Pécs.

Laczkó Tamás, Rétsági Erzsébet (2015): A sport társadalmi aspektusai. Pécsi Tudományegyetem Egészségtudományi Kar.

Lampek Andrea, Kívés Zsuzsanna (2014): Egészségmagatartás. In.: Lampek K. (szerk.) Férfiegészség. Budapest.

Makai Alexandra (2019): A felnött lakosság firikai aktivitásának és szocio-demográfiai jellemzöinek összefüggései kvantitativ vizsgálatok és egy egészségprogram tükrében. Doktori disszertáció, Pécsi Tudományegyetem Egészségtudományi Kar Egészségtudományi Doktori Iskola

Németh Ágnes. (2016): Fizikai aktivitás és képernyőhasználat. In Németh Ágnes és Költő András (Szerk.). Egészség és egészségmagatartás iskoláskorban 2014. Az Iskoláskorú gyermekek egészségmagatartása elnevezésű, az Egészségügyi Világszervezettel együttműködésben meg- valósuló nemzetközi kutatás 2014. évi felméréséről készült nemzeti jelentés, 31- 45.

Norris R, Carroll D, Cochrane R. The effects of physical activity and exercise training on psychological stress and well-being in an adolescent population. J Psychosom Res. 1992;36(1): 5565. doi. 10.1016/0022-3999(92)90114-H

Pfau Christa, Pető Károly és Bácsné Bába Éva (2018): A fizikai aktivitás, mint egészségbefektetés. Egésaségfejlesztés, 60 (1): 31-44.

Pikó Bettina, Pluhár Zsuzsanna, Keresztes Noémi (2004): Külső kényszer vagy belső hajtóerő? : serdülők fizikai aktivitásának motivációs tényezői. Alkealmazott pszichológia, 6. köt. (3): 4054.

Pluhár Zsuzsa, Keresztes Noémi és Pikó Bettina (2004): A rendszeres fizikai aktivitás és a pszichoszomatikus tünetek kapcsolata általános iskolások körében. Sportorvosi Sz̨emle, 45(4): 285300 .

Révész László, Boronyai Zoltán, Rétsági Erzsébet, Vass Zoltán, Csányi Tamás (2014): A testnevelés oktatás módszertani kérdései a mindennapos testnevelés fényében. Magyar Sporttudományi Szemle, 15 (58): 1-57.

Soós I., Hamar P., Biddle S., Huszár Á. (20102011): Az ülő életmód és a fizikai aktivitás magyarországi összefüggéseinek vizsgálata EMAmódszerrel. Kalokagathia, 4-1. 19-27.

Tahin Tamás, Jeges Sára és Lampek Kinga. (2000): Iskolai végzettség és egészségi állapot. Demográfia, 43 (1): 70-93.

Tokaji Károlyné, Faragó Miklós, Boros Julianna (2011): Objektíven szubjektív. Statisz̨tikai Szemle, 89 (7-8): 768-789.

WHO (2010): Global recommendations on physical activity for health. 58 . 